See discussions, stats, and author profiles for this publication at: https://www.researchgate.net/publication/281861284

\title{
The International Rule of Law in the Cycle of Contestations and Deference
}

Chapter - January 2016

CITATIONS

0

2 authors:

(2) Machiko Kanetake

Utrecht University

42 PUBLICATIONS 81 CITATIONS

SEE PROFILE
READS

136

2. Andre Nollkaemper

University of Amsterdam

201 PUBLICATIONS 1,273 CITATIONS

SEE PROFILE

Some of the authors of this publication are also working on these related projects:

Shared Responsibility in International Law View project 
这 UNIVERSITY OF AMSTERDAM

\title{
THE INTERNATIONAL RULE OF LAW IN THE CYCLE OF CONTESTATIONS AND DEFERENCE
}

\author{
Machiko Kanetake \\ André Nollkaemper
}

Amsterdam Law School Legal Studies Research Paper No. 2015-33

Amsterdam Center for International Law No. 2015-14 


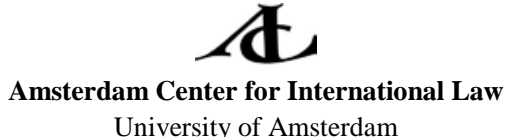

University of Amsterdam

\title{
RESEARCH PAPER SERIES
}

\author{
ACIL Research Paper 2015-14 \\ The International Rule of Law \\ in the Cycle of Contestations \\ and Deference
}

Machiko Kanetake \& André Nollkaemper

Utrecht University \& Amsterdam Center for International Law

Cite as: ACIL Research Paper 2015-14, available at www.acil.uva.nl and SSRN

Forthcoming in: Machiko Kanetake \& André Nollkaemper (eds.), The Rule of Law at the National and International Levels: Contestations and Deference, Oxford: Hart Publishing (2016) 
Draft chapter for M. Kanetake and A. Nollkaemper (eds.), The Rule of Law at the National and International Levels: Contestations and Deference (Oxford: Hart Publishing).

\title{
The International Rule of Law in the Cycle of Contestations and Deference
}

Machiko Kanetake \& André Nollkaemper

\author{
I National Contestations \\ II International Deference \\ III Problems of Uncertainty and Particularity \\ IV The International Rule of Law beyond Compliance
}

The requirement of the 'rule by law' ${ }^{1}$ is commonly considered as one of the integral elements of the rule of law. ${ }^{2}$ This formalistic requirement is arguably constitutive, not only of the rule of law in the national legal order, but also of the rule of law which has been developing in the international legal order. This is in part illustrated by the fact that the discourse concerning the rule of law at the 'international' level ${ }^{3}$ tends to underline the primary importance of compliance, as an extension of the 'rule by law' concept, with international law by states and other subjects of international law. For instance, UN Secretary-General Annan in his 2012 report prepared for the high-level meeting of the General Assembly ${ }^{4}$ foremost referred to 'compliance' with international law as a step to strengthen the international rule of law. ${ }^{5}$ The invigoration of international courts and tribunals ${ }^{6}$ has arguably heightened the significance of compliance ${ }^{7}$ which is indeed regarded as the core element of legality and the rule of law. ${ }^{8}$

\footnotetext{
${ }^{1}$ Albert Venn Dicey, Introduction to the Study of the Law of the Constitution (Indianapolis, Liberty Fund, 1982) 110-113 (first requirement). See Simon Chesterman, 'An International Rule of Law?’ (2008) 56 American Journal of Comparative Law 331, 342 (a 'government of laws' as the first core definition of the rule of law).

2 See chapter 1 (Kanetake), sect II.B.

${ }^{3}$ As noted in various contributions of this volume, the UN General Assembly has given recognition not only to the rule of law at the national level, but also to the rule of law at the 'international' level: eg, 2005 World Summit Outcome, UN Doc. A/RES/60/1 (24 October 2005), para 134; UN Doc. A/RES/61/39 (18 December 2006).

${ }^{4}$ See UN General Assembly Resolution adopted on 24 September 2012, 'Declaration of the High-level Meeting of the General Assembly on the Rule of Law at the National and International Levels' UN Doc. A/RES/67/1 (30 November 2012).

${ }^{5}$ See Report of the Secretary-General, 'Delivering Justice: Programme of Action to Strengthen the Rule of Law at the National and International Levels’ UN Doc. A/66/749 (16 March 2012), sec II.A.1.

${ }^{6}$ On the political and judicial impact of international courts, see, eg, Karen J Alter, The New Terrain of International Law: Courts, Politics, Rights (Princeton, New Jersey, Princeton University Press, 2014);
} 
Contestations in the national legal order discussed in this volume would be considered problematic if one assimilates the international rule of law with national compliance. Part I of the present volume exposed the proliferation of national practices that avoid, reinterpret, review, and reject international law or (especially in a dualist state in which treaties have no automatic domestic validity) national regulation that implements international law. As demonstrated by the chapters of Veronika Fikfak, Mateja Steinbrück Platiše, Shotaro Hamamoto, and Prabhash Ranjan, various signs of disagreement extend to international security law, international immunity law, international investment law, and international human rights law. ${ }^{9}$ Their chapters also showed that contestations emanate from multiple branches of states and have been justified on the basis of both constitutional and international law. National contestations immediately or cumulatively lead to a state of discrepancy between the actual conduct of state institutions on the one hand, and international obligations as interpreted and applied by international organisations, international courts, and treaty-monitoring bodies, on the other hand.

At the same time, part II of this volume informed us that such a discrepancy needs not be understood as being in opposition to the idea of the rule of law, but can be the source of dynamic interactions and mutual learning between relevant actors, and thereby between the two legal orders as such. National contestations can encourage international organisations and their member states to reflect on, and improve, decision-making processes within the organisations. Confrontational practices also motivate international courts and treaty-monitoring bodies to revise the extent to which they leave the margin to national decision-makers. The enduring cycles of national resistance and international adjustment, despite many shortcomings, present us a complex picture on the rule of law in the international legal order which continues to value compliance yet simultaneously respects diversity, self-determination, and the democratic legitimacy of decision making in national legal orders.

Armin von Bogdandy and Ingo Venzke (eds), International Judicial Lawmaking: On Public Authority and Democratic Legitimation in Global Governance (Berlin; New York, Springer, 2012); Armin Von Bogdandy and Ingo Venzke, In Whose Name? A Public Law Theory of International Adjudication (Oxford University Press, 2014). Kingsbury notes that the growth in the activities of international courts and tribunals posed the problem on the connection between these international bodies and national law and institutions: Benedict Kingsbury, 'Foreword: Is the Proliferation of International Courts and Tribunals a Systemic Problem’ (1998) 31 New York University Journal of International Law and Politics 679, 694.

${ }^{7}$ For empirical analyses on compliance with international judicial decisions, see, eg, Constanze Schulte, Compliance with Decisions of the International Court of Justice (Oxford; New York, Oxford University Press, 2004); Sara McLaughlin Mitchell and Paul R Hensel, 'International Institutions and Compliance with Agreements’ (2007) 51 American Journal of Political Science 721; Courtney Hillebrecht, 'Rethinking Compliance: The Challenges and Prospects of Measuring Compliance with International Human Rights Tribunals’ (2009) 1 Journal of Human Rights Practice 362. As Shany observes, however, compliance is not always the reliable indicator in understanding the effectiveness of international courts: see Yuval Shany, Assessing the Effectiveness of International Courts (Oxford University Press, 2014).

8 See Alexandra Huneeus, 'Compliance with Judgments and Decisions' in C Romano, KJ Alter and Y Shany (eds), Oxford Handbook of International Adjudication (Oxford University Press, 2013) 437, 440.

${ }^{9}$ Chapters 2 (Fikfak), 3 (Platiše), 4 (Hamamoto), 5 (Ranjan) of the present volume. 


\section{National Contestations}

There is nothing novel in the practices of states that avoid and resist the domestic application of treaties and the internationally binding decisions of international organisations and international courts. To name a few well-known instances, South Africa under the apartheid regime rejected the UN Security Council's economic sanctions for many years; ${ }^{10}$ the US government dismissed the judgments of the International Court of Justice (ICJ) in Nicaragua $(1984,1986) ;{ }^{11}$ and Iran rejected the ICJ's judgment in the Hostage case $(1979,1980) .{ }^{12}$ In addition, each state's general amenability to international law is conditioned by many long- and short-term factorssuch as the state's (dis)connection with the historical genesis of international law, languages, education of lawyers regarding international law, monist-dualist traditions on the domestic validity of treaties, and specific governmental policies.

However, the materials discussed in part I of this volume allowed us to capture some patters of national contestations in a more systematic way. The main confrontational practices analysed in this volume and the wider literature can be organised in terms of the diversity of sources of international law that are being contested (A), the variety of national organs that engage in contestations (B), and the standards of review (C).

\section{A Contested International Law and Decisions}

The contributions to this volume demonstrated that the scope of potentially resistible international law and decisions has enlarged, not only by the expansion of the subject matter overlap between national and international law, ${ }^{13}$ but also by the invigoration of

\footnotetext{
${ }^{10}$ The UN Security Council imposed a mandatory arms embargo under Resolution 418: UN Doc. S/RES/418 (4 November 1977). South Africa defied the sanctions for many years: see eg, UN Doc A/RES/40/64 (10 December 1985) para 3 ('Condemns the South African racist regime for defying resolutions of the United Nations ...'). On South Africa's approaches to international law, see Robert Kolb, Interprétation et création du droit international: Esquisses d'une herméneutique juridique moderne pour le droit international public (Bruxelles, Bruylant, 2006) 68-69; John Dugard, International Law: A South African Perspective (4th edn, Juta, 2011).

${ }^{11}$ Military and Paramilitary Activities in and against Nicaragua (Nicaragua v United States of America), Jurisdiction and Admissibility (1984) 1984 ICJ Reports 392, (Judgment of 26 November 1984); Military and Paramilitary Activities in and against Nicaragua (Nicaragua v United States of America), Merits (1986) [1986] ICJ Reports 14 (Judgment of 27 June 1986). On the US’s approaches to the ICJ decisions, see Andreas L Paulus, 'From Neglect to Defiance? The United States and International Adjudication' (2004) 15 European Journal of International Law 783.

${ }^{12}$ United States Diplomatic and Consular Staff in Tehran (United States of America v Iran) (Provisional Measures) [1979] ICJ Reports 7 (Provisional Measures, Order of 15 December 1979); United States Diplomatic and Consular Staff in Tehran (United States of America v Iran) [1980] ICJ Reports 3 (Merits, Judgment of 24 May 1980).

${ }^{13}$ International treaties and customary international law prescribe principles and rules concerning, for instance, human rights, criminal justice, environment, development, investment, and intellectual property, which are likewise regulated by constitutional law and other domestic laws: see eg, Anne-Marie Slaughter and William Burke-White, 'The Future of International Law Is Domestic (or, the European Way of Law)' (2006) 47 Harvard International Law Journal 327.
} 
international institutions, especially the UN Security Council, ${ }^{14}$ and international courts. ${ }^{15}$ First, the political decisions of international organisations have been subject to direct or indirect contestations at the domestic level. In this volume, Veronika Fikfak recalled that this is most notably illustrated by $\mathrm{Kadi}^{16}$ and related judicial contestations regarding the human rights (in)compatibility of the regulation implementing the decisions of the UN Security Council and its sanctions committees to designate certain individuals and entities for the purpose of the UN's targeted sanctions regimes. ${ }^{17}$

Second, the judicial decisions of international courts have been subject to critical scrutiny at the domestic level. In international human rights law, the decisions of the Inter-American Court of Human Rights (IACtHR) have been constantly avoided and rejected at the national level. ${ }^{18}$ While the national compliance is much more secured with regard to the ECtHR's decisions, national judges still utilise their interpretive discretion in giving effect to ECtHR judgments in domestic law, ${ }^{19}$ and also explicitly contradict them, as the UK Supreme Court's decision in Horncastle (2009) ${ }^{20}$ declined to follow Al-Khawaja and Tahery $v$ UK $(2009)^{21}$ regarding the compatibility of hearsay evidence with the right to a fair trial under the European Convention on Human Rights (ECHR) ${ }^{22}$ As elaborated on in this volume by Hamamoto, in the field of international investment law, the British Columbia Supreme Court in Mexico $v$ Metalclad Corporation (2001) set aside part of an award under the North American Free Trade Agreement (NAFTA) Chapter $11 .^{23}$

\footnotetext{
${ }^{14}$ On the invigoration of the UN Security Council and its impact on individuals, see, eg, Erika De Wet, The Chapter VII Powers of the United Nations Security Council (Oxford; Portland Oregon, Hart Publishing, 2004).

${ }^{15}$ On the political and judicial impact of international courts, see, eg, Alter, The new terrain of international law (n 6); Bogdandy and Venzke, International Judicial Lawmaking: On Public Authority and Democratic Legitimation in Global Governance (n 6); Bogdandy and Venzke, In Whose Name? (n 6). and Political Activism in Latin America (Cambridge University Press, 2010) 112; Alexandra Huneeus, 'Courts Resisting Courts: Lessons from the Inter-American Court's Struggle to Enforce Human Rights' (2011) 44 Cornell International Law Journal 493.

${ }^{19}$ See Nico Krisch, 'The Open Architecture of European Human Rights Law’ (2008) 71 Modern Law Review 183.

${ }^{20} R$ v Horncastle and Others [2009] UKSC 14 (9 December 2009). Lord Phillips observed (as agreed upon by all judges) that it is ‘open to [the] court to decline to follow the Strasbourg decision' if it fails to sufficiently accommodate particular aspects of the UK's domestic process: ibid para 11. Similarly, ibid, paras 107-8 (Lord Phillips), 117-21 (Lord Brown).

${ }^{21}$ Al-Khawaja and Tahery $v$ The United Kingdom App nos 26766/05 and 22228/06, [2009] 49 EHRR 1 (ECtHR, 20 January 2009). The judgment in Al-Khawaja (2009) was in turn based upon the earlier jurisprudence of the ECtHR, including: Lucà v Italy App no 33354/96, ECHR 2001-II (ECtHR, 27 February 2001), para 40 (Article 6 is infringed upon 'where a conviction is based solely or to a decisive degree on depositions that have been made by a person whom the accused has had no opportunity to examine or to have examined').

22 See also (n 76) below and corresponding text.

${ }^{23}$ Mexico v Metalclad Corporation (2001) 2001 BCSC 664 (The Supreme Court of British Columbia, 2 May 2001). For a detailed analysis, see chapter 4 (Shotaro Hamamoto) of this volume.
} 
Third, national contestations can be seen even with regard to formally non-binding instruments adopted by treaty-monitoring bodies, such as those for UN human rights treaties. ${ }^{24}$ Despite the lack of formal binding force, ${ }^{25}$ the bodies' documents inform the domestic interpretation of human rights treaties and of constitutional and statutory human rights provisions. ${ }^{26}$ However, domestic courts occasionally reject and contest the monitoring bodies' findings explicitly through their reasoning or implicitly by the consequences of their decisions, as illustrated by Jones v Saudi Arabia (2006), in which the UK judges apparently disagreed with the treaty interpretation put forward by the Committee against Torture's Observations. ${ }^{27}$

Finally, treaty provisions and customary international law themselves are also subject to national contestations. As analysed in this volume by Mateja Steinbrück Platiše, the jurisdictional immunity of international organisations, which international law protects under the broad notion of functional necessity, ${ }^{28}$ has met the jurisprudence of national courts that attempt to restrict it. ${ }^{29}$ The German Constitutional Court in Solange I $(1974)^{30}$ and Solange II (1986) ${ }^{31}$ famously conditioned the human rights review of the

\footnotetext{
${ }^{24}$ Human Rights Committee (HRC), Committee on Economic, Social and Cultural Rights (CESCR), Committee on the Elimination of Racial Discrimination (CERD), Committee on the Elimination of Discrimination against Women (CEDAW), Committee against Torture (CAT), Subcommittee on Prevention of Torture (SPT), Committee on the Rights of the Child (CRC), Committee on Migrant Workers (CMW), Committee on the Rights of Persons with Disabilities (CRPD), and Committee on Enforced Disappearances (CED). On UN human rights treaty-monitoring bodies, see, eg, Philip Alston and James Crawford (eds), The Future of UN Human Rights Treaty Monitoring (Cambridge, Cambridge University Press, 2000).

${ }^{25}$ On the analysis of binding character (under international and national law) of the instruments adopted by UN human rights treaty-monitoring bodies, see Rosanne van Alebeek and André Nollkaemper, 'The Legal Status of Decisions by Human Rights Treaty Bodies in National Law' in H Keller and G Ulfstein (eds), UN Human Rights Treaty Bodies: Law and Legitimacy (Cambridge, Cambridge University Press, 2012) 356.

${ }^{26}$ See further ILA, Committee on International Human Rights Law and Practice, 'Final Report on the Impact of Findings of the United Nations Human Rights Treaty Bodies' (2004). See also Machiko Kanetake and André Nollkaemper, 'The Application of Informal International Instruments Before Domestic Courts’ (2014) 46 The George Washington International Law Review 765.

${ }^{27}$ Jones v Saudi Arabia [2006] UKHL 26; (2007) 1 AC 270 (UK, House of Lords, 14 June 2006); UN Committee Against Torture, 'Conclusions and Recommendations: Canada' CAT/C/CR/34/CAN (7 July 2005) paras 4(g), 5(f). In Jones v Saudi Arabia, having noted the Committee’s critical remark regarding Canada's state report, Lord Bingham dismissed the relevance of the Committee's observation, noting that ' $[w]$ hatever its value in influencing the trend of international thinking, the legal authority of the Committee's recommendation is slight' (Jones v Saudi Arabia, ibid, para 23). Lord Hoffmann found 'no value' in the Committee's position (ibid, para 57). The Committee's interpretation was further disagreed with by the ECtHR in Jones $v$ UK: see UN Committee Against Torture, 'Concluding Observations of the Committee against Torture: Canada’ CAT/C/CAN/CO/6 (25 June 2012) paras 14-15; Committee Against Torture, 'General Comment No 3 (2012): Implementation of Article 14 by States Parties' CAT/C/GC/3 (13 December 2012) paras 22, 42; Jones and Others v The United Kingdom App nos 34356/06 and 40528/06 (ECtHR, 14 January 2014), para 208.

${ }^{28}$ See chapter 3 (Mateja Steinbrück Platiše), sec II.

${ }^{29}$ See chapter 3 (Mateja Steinbrück Platiše), sec III.

${ }^{30}$ Internationale Handelsgesellschaft v Einfuhr- und Vorratstelle für Getreide und Futtermittel [1974] CMLR 540 (Germany, Federal Constitutional Court, 29 May 1974).

${ }^{31}$ In reapplication of Wünsche Handelsgesellschaft, Federal Constitutional Court, [1987] 3 CMLR 225 (Germany, Federal Constitutional Court).
} 
acts of the European Community (EC) on the availability of comparable protection at the European level. The Solange reasoning has been applied to the acts of the EC/EU and other international organisations by several domestic courts in Switzerland, Italy, the US, Argentina, and Columbia. ${ }^{32}$ As illustrated by these examples, the subject matter overlap has created the opportunities for both the harmonisation of national regulation according to international law, and the occasions in which national organs encounter difficulties in absorbing it into the domestic legal systems.

\section{B Domestic Actors Engaging in Contestations}

In expressing certain dissatisfaction about international law, various state organs do not speak with one voice. Executive, legislative, and judicial bodies have varied interests using and challenging international law and decisions of international organisations and courts. ${ }^{33}$ Rene Urueña in this volume suggested that international legal scholars tend to overlook the variance at the domestic level. ${ }^{34}$

National courts, although there is nothing novel for them to encounter a conflict between domestic law and the rules of international law, ${ }^{35}$ may be becoming less hesitant to place stronger trust in their own domestic constitutional law and avoid and reject internationally binding rules and decisions. ${ }^{36}$ Domestic courts contest directly or indirectly such rules and decisions even against the willingness of political organs to give domestic effect to them. The contrast of Medellin (2008) ${ }^{37}$ before the US Supreme Court and the Italian Constitutional Court's decision no 238/2014 ${ }^{38}$ illustrates this point. While both the US Supreme Court and the Italian Constitutional Court declined to give effect to the ICJ's judgments in Avena (2004) ${ }^{39}$ and Germany $v$ Italy (2012) ${ }^{40}$ respectively, the US court in Medellin left it to the Congress to decide whether a nonself-executing treaty-in this case, the ICJ's decision in Avena-could be enforceable at

\footnotetext{
${ }^{32}$ For details, see chapter 3 (Mateja Steinbrück Platise), sec III(C).

${ }^{33}$ In relation to the national implementation of the Inter-American Court of Human Rights, Huneeus observes that the implementation involves 'disparate state actors whose interests, ideologies, and institutional settings differ ...': Huneeus, ‘Courts Resisting Courts’ (n 18) 495.

${ }^{34}$ Chapter 6 (Rene Urueña) of this volume.

35 See HF van Panhuys, 'Relations and Interactions Between International and National Scenes of Law' (1964) 112 Recueil des Cours 1, 34-48.

${ }^{36}$ Waters observes that judicial dialogues-both vertically between national and international courts and horizontally among national courts-may have incrementally altered the identity of national courts not only as domestic legal agents but also as contributing to international legal norms: see Melissa A Waters, 'The Future of Transnational Judicial Dialogue' (2010) 104 Proceedings of the Annual Meeting (American Society of International Law) 465, 465-66.

${ }^{37}$ Medellín v Texas (2008) 128 S.Ct. 1346 (US Supreme Court, Judgment of 25 March 2008).

38 Sentenza n 238, Anno 2014 (Italy, Constitutional Court, 22 October 2014), English translation is also available at http://www.cortecostituzionale.it/documenti/download/doc/recent_judgments/S238_2013_en.pdf (last accessed 1 June 2015).

${ }^{39}$ Avena and Other Mexican Nationals (Mexico v United States of America) [2004] ICJ Reports 12.

${ }^{40}$ Jurisdictional Immunities of the State (Germany $v$ Italy : Greece intervening) [2012] ICJ Reports 99 (3 February 2012). In this case, the ICJ found Italy’s internationally wrongful acts in disregarding the international customary law to grant Germany immunity from civil suit.
} 
the domestic level. ${ }^{41}$ By contrast, the Italian court declined to defer to the decisions of the Italian parliament which had obliged judges to give effect to the ICJ's judgment. ${ }^{42}$

Political resistance against international law can stem from legislative and executive organs as well as from the wider public. As pointed out in the chapter by Rene Urueña, while lawyers tend to focus on the role of national courts, non-judicial national organs obviously play a crucial role in accepting or rejecting international law at the domestic level. ${ }^{43}$ For instance, there have been longstanding political oppositions against the ECtHR and its particular decisions. The UK initiated the public debate on the possible withdrawal from the ECHR in 1956, ${ }^{44}$ and the opposition persists in the 1990s especially after the ECtHR's decision in McCann $v$ UK (1995). ${ }^{45}$ In response to in Hirst $\checkmark U K$ (No 2) (2005) ${ }^{46}$ over the prisoners' voting entitlement, in which the ECtHR concluded that the general restriction on the rights to vote exceeded any acceptable margin of appreciation, ${ }^{47}$ UK Parliament expressed its resistance against the ECtHR by stating that the decisions on the prisoners' right to vote 'should be a matter for democratically-elected lawmakers', ${ }^{48}$

Political resistance also continues to surface with regard to the particular decisions of international investment tribunals, dispute settlement mechanisms under investment treaties, and even such treaty mechanisms themselves. As exposed by Prabhash Ranjan's chapter, Ecuador denounced several bilateral investment treaties (BITs), South Africa terminated several BITs, Bolivia and Ecuador withdrew from the ICSID, Australia decided not to have an investor-state dispute resolution mechanism, and India reviewed the existing BITs in order to better secure the host state's regulatory power. ${ }^{49}$

As Ji Li argued in this volume, these contestations from judicial and non-judicial forums cannot be separated from wider social norms that underline such contestations against international law and institutions. ${ }^{50}$ Governmental officials decide whether and how they use international law and the decisions of international institutions at the domestic level, and such officials’ attitude towards international law is constructed by their social

\footnotetext{
${ }^{41}$ Medellín v Texas (n 37) 1368.

${ }^{42}$ Legge 17 agosto 1957, n 848 [Law no 848 of 17 August 1957], Gazzetta ufficiale (GU), n 238 (25 September 1957), art 1; Legge 14 gennaio 2013, n 5 [Law no 5 of 14 January 2013], in GU, n 24 (29 January 2013), art 3 ('Esecuzione delle sentenze della Corte internazionale di giustizia').

${ }^{43}$ Chapter 6 (Rene Urueña) of this volume, sec III.

${ }^{44}$ The debate was in relation to the case brought by Greece against the UK: Greece $v$ The United Kingdom App no 176/56, Decision of the Commission on the Admissibility of the Application (2 June 1956).

${ }^{45}$ McCann and Others $v$ The United Kingdom App no 18984/91, Series A no 324 (ECtHR, Grand Chamber, 27 September 1995).

${ }^{46}$ Hirst v United Kingdom (No 2) App. No 74025/01, ECHR 2005-IX (ECtHR, Grand Chamber, 6 October 2005).

47 ibid para 82.

${ }^{48}$ House of Commons Votes and Proceedings, Sessions 2010-11, No 115, 10 February 2011, at < http://www.publications.parliament.uk/pa/cm201011/cmvote/110210v01.htm> (234 in favour, 22 against).

${ }^{49}$ See chapter 5 (Prabhash Ranjan) of this volume, sec III (B).

${ }^{50}$ Chapter 7 (Ji Li) of this volume.
} 
and cultural backgrounds. ${ }^{51}$ Domestic legal, political, and cultural factors alter the level of compliance by states of the judgments of international courts. ${ }^{52}$

\section{Standards of Review}

The contributions to this volume further suggested that relevant actors can contest international law on the basis of national and/or international law which, in substance, can overlap one another.

\section{National law}

The reliance on national law indicates that domestic constitutional law and other national legal principles and rules themselves allow space for contestations. In the Italian Constitutional Court's aforementioned decision no 238/2014, ${ }^{53}$ for instance, judges conducted review on the basis of the fundamental principles of the domestic legal order, including the principles of protection of fundamental human rights, ${ }^{54}$ in light of which the relevant laws were found disproportionately restricting the 'fundamental principles of the constitutional order', ${ }^{55}$ including the constitutional right of access to justice. ${ }^{56}$ Likewise, albeit in the context of EU law, the Court of Justice in Kadi I (2008) upheld the autonomy of the EU legal order based upon the 'rule of law', which allowed the Court of Justice to conduct the 'full review' of the contested EU (then EC) regulation. ${ }^{57}$

\footnotetext{
${ }^{51} \mathrm{See}$, in the context of trade dispute resolution, chapter 7 ( $\mathrm{Ji} \mathrm{Li}$ ) of this volume.

52 Huneeus, ‘Compliance with Judgments and Decisions’ (n 8) 453-57.

53 Sentenza n 238 (n 38).

54 See Sentenza n 238, Anno 2014 (Italy, Constitutional Court, 22 October 2014), para 3.1, English translation is also available at http://www.cortecostituzionale.it/documenti/download/doc/recent_judgments/S238_2013_en.pdf (last accessed 1 June 2015).

${ }^{55}$ Sentenza n 238 (n 38) para 3.2 ('i principi fondamentali dell’ordinamento costituzionale’).

${ }^{56}$ See Sentenza n 238 (n 38) paras 3.4, 4-5. The Italian Constitutional Court found the general provision of the domestic law that obliged the national judges to comply with the ICJ judgments were contrary to the judicial protection which is guaranteed by Art 24 of the Italian Constitution. According to the Italian Constitutional Court, the fact that the Court is not in a position to examine the ICJ's qualified interpretation of customary international law does not mean that the Italian Court does not decide upon the conflict between international norms and Constitutional norms and principles: see Sentenza n 238 (n 38) paras 3.1, 3.3.

${ }^{57}$ Cases C-402/05 P and C-415/05 P Kadi and Al Barakaat International Foundation v Council of the European Union and Commission of the European Communities [2008] ECR I-06351 (ECJ) (Judgment of 3 September 2008). On the 2008 judgment, see, eg, Deirdre Curtin and Christina Eckes, 'The Kadi Case: Mapping the Boundaries between the Executive and the Judiciary in Europe' (2008) 5 International Organizations Law Review 365; Christina Eckes, EU Counter-Terrorist Policies and Fundamental Rights (Oxford University Press, 2009) chap 5; Paul James Cardwell, Duncan French and Nigel White, 'European Court of Justice, Yassin Abdullah Kadi and Al Barakaat International Foundation v Council and Commission (Joined Cases C-402/05 P and C-415/05 P) Judgment of 3 September 2008' (2009) 58 International \& Comparative Law Quarterly 229; Grainne de Burca, 'The European Court of Justice and the International Legal Order after Kadi’ (2010) 51 Harvard International Law Journal 1.
} 
At the same time, the review of the national implementation of international law, formally based upon the national standards of review, can also provide feedback to the international legal order. First, as indicated by Veronika Fikfak in this volume, in the course of ultimately reviewing the relevant implementing legislation, judges may critically analyse the original decisions of international courts and international organisations. ${ }^{58}$ For instance, the Court of Justice in Kadi II (2013), having intensified the level of full review, scrutinised the UN's listing process in detail, ${ }^{59}$ although the Court of Justice's review was ultimately for EU regulation on the basis of the fundamental rights in the EU legal order. Also, as demonstrated by Mateja Steinbrück Platiše in this volume, national judges examine the purpose and scope of the immunities traditionally granted to international organisations under international law; by so doing, domestic courts highlight the shortcomings - in the eyes of national courts - of international law concerning the immunities of international organisations. ${ }^{60}$

Second, the national standards of review can be enriched by international treaties, especially international human rights treaties. Although the Italian Constitutional Court in its decision no $238 / 2014^{61}$ employed the constitutional right of access to justice as a basis for declining to give effect to the ICJ judgment, the decision, through the substantive connection between the constitutional right in question and the right to access to justice under international law, effectively provides critical feedback to international law on state immunity as interpreted by the ICJ. ${ }^{62}$

\section{International Law}

International law itself has been a facilitator of national contestations. As examined by Mateja Steinbrück Platiše's chapter, the fact that the ECtHR in Waite \& Kennedy has effectively adopted the Solange reasoning at the international level further empowered domestic courts to condition the grant of international organisations' immunity on the availability of alternative remedies; for instance, the Belgian Court of Appeals in Siegler $v$ Western European Union resorted to the Waite \& Kennedy test ${ }^{63}$ and found the organisation's jurisdictional immunity incompatible with Article 6(1) (the right to a fair

\footnotetext{
${ }^{58}$ See chapter 2 (Veronika Fikfak) of this volume, about the different modalities of judicial review.

${ }^{59}$ The Court of Justice assessed (i) whether one of the reasons (for listing) stated in the summary provided by the UN's Sanctions Committee was sufficiently detailed and specific and (ii) whether it is substantiated: see Joined cases C-584/10 P, C-593/10 P and C-595/10 P, Kadi v European Commission (ECJ) (Judgment of 18 July 2013), paras 114-16, 118-119, 125-28, 130. (i) With regard to the former, the Court of Justice acknowledged that some of the reasons stated in the Sanctions Committee's summary were sufficiently detailed and specific: Kadi (ECJ, 2013), ibid, paras 140-50. (ii) Nevertheless, for the latter, the Court of Justice found that information or evidence which might have substantiated the reason for listing was absent, and thereby annulled the contested EU regulation that implemented the decisions of the UN sanctions committees' decisions: Kadi (ECJ, 2013), ibid, paras 151-64.

${ }^{60}$ See chapter 3 (Mateja Steinbrück Platiše) of this volume.

${ }^{61}$ Sentenza n 238 (n 38).

${ }^{62}$ See Pasquale De Sena, 'The Judgment of the Italian Constitutional Court on State Immunity in Cases of Serious Violations of Human Rights or Humanitarian Law: A Tentative Analysis Under International Law' (2014) Questions of International Law, Zoom Out II 17.

${ }^{63}$ Siegler v Western European Union, Journal des Tribunaux (JT) 2004, 617, ILDC 53 (BE 2003)

(Brussels Labour Court of Appeal, 17 September 2003), paras 50-51.
} 
trial) of the ECHR. ${ }^{64}$ While relying on the ECtHR's jurisprudence, the Belgium court conducted a more detailed assessment of the internal procedure of the international organisations against the essential conditions of the right to a fair trial. ${ }^{65}$

As reminded by Veronika Fikfak in this volume, national and EU courts also directly reviewed the decisions of the UN Security Council on the basis of jus cogens norms. ${ }^{66}$ In the September 2005 judgment in Kadi I, the General Court (then the Court of First Instance) engaged in jus cogens review while recognising the UN Charter's primacy which structurally limited the Court's judicial review. ${ }^{67}$ This is the case in which the EU court employed, as a standard of review, the international rule of law standards regulating authority exercised by the UN Security Council. The use of jus cogens also illustrates the formalistic and thin character of the international rule of law regulating the UN, as contrasted with more substantive and thicker rule of law standards applicable to national organs. ${ }^{68}$

\section{International Deference}

As noted at the beginning of this chapter, national contestations may appear to be a threat to the international rule of law if the latter is understood as requiring full compliance. However, as demonstrated by this volume, domestic contestations incrementally invited procedural or substantive changes on the part of international institutions. As suggested by the chapters of Jennifer Easterday and Stephan Schill, national and international law are dependent on each other in order to achieve certain purposes; this inter-dependency renders both national authorities and international institutions receptive to each other's demands. On this basis, we argue that this cycle of national contestations and international responses is an essential feature of the international rule of law.

\footnotetext{
${ }^{64}$ Siegler v Western European Union (n 63), para 63.

${ }^{65}$ Siegler v Western European Union (n 63), paras 59-62. See Maarten Vidal, 'Analysis: Siedler v. Western European Union', ILDC 53 (BE 2003), paras A3-A5.

${ }^{66}$ Chapter 2 (Veronika Fikfak) of this volume.

${ }^{67}$ See Case T-315/01 Yassin Abdullah Kadi $v$ Council of the European Union and Commission of the European Communities [2005] ECR II-03649 (CFI) (Judgment of 21 September 2005), para 226. The CFI's jus cogens review was, however, based upon the extremely brief assessment on the concept and scope of jus cogens norms and proceeded with its own notion of jus cogens: see Joris Larik, 'Two Ships in the Night or in the Same Boat Together? Why the European Court of Justice Made the Right Choice in the Kadi Case' (2009) College of Europe EU Diplomacy Paper No 3/2009 6-10. Cf. Andrew Hudson, 'Not a Great Asset: The UN Security Council's Counter-Terrorism Regime: Violating Human Rights' (2007) 25 Berkeley Journal of International Law 203, 216-222 (observing that the right to a fair hearing is part of jus cogens, and that the 1267 sanctions regime breaches the core procedural guarantees protected by the right to a fair hearing).

${ }^{68}$ See Machiko Kanetake, 'The Interfaces between the National and International Rule of Law: The Case of UN Targeted Sanctions’ (2012) 9 International Organizations Law Review 267, 286-87.
} 


\section{A International Procedural Reforms}

Such a cycle can be seen first with regard to the practice of the political organs of international organisations. National contestations against the decisions of such organs can encourage the organs' reforms to improve the transparency and accountability of international decision-making procedures by taking into account the national rule of law standards. As a good illustration, Kadi and other judicial contestations facilitated political momentum at the UN for procedural reforms, ${ }^{69}$ leading to the incremental procedural improvements at the UN Security Council's sanctions committees. ${ }^{70}$ Domestic contestations with regard to the scope of immunities in part encouraged international organisations to revise the scope of immunities. Such a trend can also be seen in the jurisprudence of international courts on the immunities of international organisations. $^{71}$ This is accompanied by the provision of internal procedures through which affected private parties can bring their claims to international organisations. ${ }^{72}$

\section{B Adjusting the National Margin}

International courts and treaty-monitoring bodies showed deference to national legal practices by adjusting the margin accorded to them. The deference to democratic legitimacy is one way to alleviate the democratic deficit in the operation of international judicial bodies themselves. As suggested by Andrew Legg in this volume, the margin of appreciation is in fact an integral part of the international rule of law. ${ }^{73}$ Birgit Peters pointed out that the principle of subsidiarity, the margin of appreciation, and the European consensus provide the frameworks through which the ECtHR engage in and respond to national courts' decisions. ${ }^{74}$ The UK Supreme Court in Horncastile also characterised its own contestations as a gateway to a "valuable dialogue, ${ }^{75}$ between the UK judiciary and the Strasbourg Court, which indeed invited adjustment by the ECtHR's Grand Chamber in al-Khawaja (2011). ${ }^{76}$ As Shai Dothan argued in this

\footnotetext{
${ }^{69}$ Among various political initiatives, noteworthy is the UN High-Level Panel's call in 2004; the Panel noted that ' $[\mathrm{t}]$ he way entities or individuals are added to the terrorist list maintained by the Council and the absence of review or appeal for those listed raise serious accountability issues and possibly violate fundamental human rights norms and conventions': Report of the High-Level Panel on Threats, Challenges and Change, A More Secure World: Our Shared Responsibility, A/59/565 (2 December 2004), para 152. For various political initiatives to call for procedural reforms, see further Machiko Kanetake, 'Enhancing Community Accountability of the Security Council through Pluralistic Structure: The Case of the 1267 Committee' (2008) 12 Max Planck Yearbook of United Nations Law 113.

${ }^{70}$ For procedural reforms, see Kanetake (n 68), Annex II (The Procedural Development of the Al Qaida Sanctions Committee).

${ }^{71}$ Chapter 3 (Mateja Steinbrück Platiše) of this volume.

${ }^{72}$ Chapter 3 (Mateja Steinbrück Platiše), sec IV(B).

${ }^{73}$ See chapter 10 (Andrew Legg) of this volume.

${ }^{74}$ Chapter 8 (Birgit Peters) of this volume.

${ }^{75}$ Horncastle (2009) (n 20) para 11 (Lord Phillips, in a judgment agreed upon by all judges).

${ }^{76}$ Al-Khawaja and Tahery $v$ The United Kingdom App nos 26766/05 and 22228/06, ECHR 2011 (ECtHR, Grand Chamber, 15 December 2011). The Grand Chamber, having analysed relevant English criminal law provisions and jurisprudence (ibid paras 40-62) and the practices of other common law jurisdictions (ibid paras 63-87), presented the jurisprudence relevant to Article 6 (fair trial) of the ECHR in a more flexible way than did the al-Khawaja decision in 2009. Considering the 'overall fairness of the
} 
volume, the ECtHR derives its own normative legitimacy by deferring to democratically accountable institutions, which also conditions the ECtHR's deference on democratic decision making at the national level. ${ }^{77}$ The cycle of contestations and deference can be seen in the context of international investment law. As analysed by Prabhash Ranjan, national contestations have facilitated both national and international debate as to how the balances can be better struck between investment protection and the host state's right to regulate in public interest. ${ }^{78}$ Of course, the degree of deference significantly varies depending on international courts and case-specific circumstances. Owing to its extensive remedial orders and the continuous monitoring of compliance, the IACtHR is known for being less deferential to the region's national legal practices which, when presented before the Court, often involve large-scale state-sponsored crimes. ${ }^{79}$

International treaty-monitoring bodies also show deference to state-specific circumstances, by engaging in a form of dialogue between the Committee on the Elimination of Discrimination against Women and state's parties. As argued by Yvonne Donders and Vincent Vleugel in this volume, the dialogue enables states to challenge the way in which universal human rights are understood by treaty-monitoring bodies, which in part induced the changes on the part of treaty-monitoring bodies. ${ }^{80}$

One particular aspect of international human rights law which is negotiated in this way is reservations to human rights treaties. Ekaterina Yahyaoui Krivenko's chapter suggested that the practices of negotiation and their outcomes constitute one of the essential elements of the international rule of law. ${ }^{81}$ As argued in her chapter, the 'reservations dialogue' allows for a constructive negotiation of diverse national legal orders into international human rights law. ${ }^{82}$

\section{Problems of Uncertainty and Particularity}

As illustrated by this volume, national contestations and international deference are part of the process for developing international law. At the same time, such a nuanced process involving a dialogue has several shortcomings. In particular, it appears to compromise the certainty of law (A) and to allow a particular version of the rule of law to contribute to the formulation of international legal practices (B).

proceedings' (ibid paras 144, 146), the Grand Chamber considered that a hearsay statement as the sole or decisive evidence does not 'automatically' lead to a violation of Article 6(1) (ibid paras 145, 147). On this basis, the safeguards in the English law were found to be in principle strong safeguards designed to ensure fairness (ibid para 151). The Grand Chamber also noted that it is not the task of the ECtHR to make abstract or general assessment on the common law rule against hearsay (ibid para 126).

77 See chapter 9 (Shai Dothan).

${ }^{78}$ Chapter 5 (Prabhash Ranjan) of this volume.

${ }^{79}$ See Huneeus, 'Courts Resisting Courts' (n 18) 496, 500-02.

${ }^{80}$ Chapter 13 (Yvonne Donders and Vincent Vleugel) of this volume

${ }^{81}$ See chapter 12 (Ekaterina Yahyaoui Krivenko) of this volume.

${ }^{82}$ Chapter 12 (Ekaterina Yahyaoui Krivenko) of this volume. 


\section{A Uncertainty}

One of the consequences of balancing competing demands for international law is to undermine certainty and foreseeability; for instance, the meaning of legal rules may be unclear when international human rights law tries to balance the demand for universality and diversity. ${ }^{83}$

One of the common criticisms for leaving greater space for cultural diversity at the national and sub-national levels is that this undermines sufficient clarity and predictability in international human rights norms, as pointed out by Yvonne Donders and Vincent Vleugel in this volume. ${ }^{84}$ Legal certainty as part of the rule of law requires treaties and treaty provisions to be sufficiently clear and precise to be predictable and foreseeable. ${ }^{85}$ The terms of human rights treaties leave the space for flexibility and diversity at the level of national implementation. Human rights treaty-monitoring bodies, such as the Human Rights Committee (for the ICCPR), provides a vital role in balancing, on the one hand, the flexibility and diversity in international human rights law, and, on the other hand, the certainty and foreseeability in the substance of human rights law. ${ }^{86}$ More specifically, the dialogue created between human rights treatymonitoring bodies and national officials has the role of formulating international human rights norms in a way which is still acceptable for state parties.

\section{B Particularity}

There is also another question whether the cycle of domestic contestations and international deference would increase the disparities among states in terms of their contribution to the development of international law.

The thickness of the rule of law at the domestic level is by no means uniform among states and regions. For instance, the rule of law in one country does not weight the protection of human rights in the same manner as another country does in its domestic legal order. The crux is that the different approaches to the rule of law at home may affect the ability of states and regions to review and criticise the decisions of international organisations and international courts at the domestic level, including before domestic courts. The adoption of the relatively thin rule of law at the domestic level might, albeit still a hypothesis, reduce the opportunities for domestic organs to directly or indirectly review and criticise the decisions of international organizations and international courts on the basis of the states' national rule of law standards.

Certain rule of law standards can be proactively pursued at the international level by the governments of some politically influential countries and regions, and the international political impact of national judicial decisions greatly varies depending upon the countries. Large disparities in political influence become problematic if certain

\footnotetext{
${ }^{83}$ See chapter 12 (Ekaterina Yahyaoui Krivenko) of this volume, introduction.

${ }^{84}$ Chapter 13 (Yvonne Donders \& Vincent Vleugel) of this volume.

${ }^{85}$ Chapter 13 (Yvonne Donders \& Vincent Vleugel) of this volume, sec II(B).

${ }^{86}$ See chapter 13 (Yvonne Donders \& Vincent Vleugel) of this volume.
} 
standards of review employed by one state or one region can be presented as universally applicable and agreeable without the involvement of wider states. In this sense, judicial contestations at the domestic level, whose legal effect of the decisions is formally confined in respective legal orders, should be understood as part of political influence and initiatives vis-à-vis international organisations, international courts, and international treaties.

\section{The International Rule of Law beyond Compliance}

The picture that emerges from the combination of Parts I and II of this book thus allows us to revise a compliance-based understanding about international law's approaches to national law and the national rule of law. International law, and international institutions that interpret and apply it, do not always command blind national obedience to international law. Instead, they incorporate a process of adjustment and deference to national law and the rule of law embedded therein. International law and institutions (eg, international human rights treaty-monitoring bodies and human rights courts) respond to national contestations (as discussed in part I of this volume) and show deference to the national rule of law (as analysed in part II).

This process of adjustment and deference across the legal orders is arguably part of the rule of law integrated in the international legal order itself. In other words, the 'international' rule of law, as evidenced by and supported by the practices discussed in this volume, is not merely about ensuring national compliance with international law; instead, the international rule of law appears to accommodate the cycle of national contestations and international responses to them. While this flexibility might come at the expense of the certainty of international law, the practice suggests that the international rule of law in relation to the national legal order seems to allow flexibility, national diversity, and pluralism.

The notion of the international rule of law presented by this volume finds further support in the statement of South Africa in 2009 during the debate on the rule of law at the UN. The South African delegation pointed out that the concept of the rule of law does not simply refer to compliance with international obligations. ${ }^{87}$ The South African delegation suggested that the concept also implies the fair and inclusive law-making process, using the non-inclusive Security Council as a point of critique. ${ }^{88}$

Ultimately, behind national contestations and international deference, there lies a much wider problem of legitimacy and accountability deficit on the part of international law and international institutions. Study of the feedback of national legal practices on the

\footnotetext{
${ }^{87}$ UN GA Sixth Committee, Summary Record of the 8th Meeting on 14 October 2009, UN Doc A/C.6/64/SR.8 (11 November 2009), paras 73-74 (Mr. Tladi of South Africa) (at the debate on 'the rule of law at the national and international levels').

${ }^{88}$ UN GA Sixth Committee, on 14 October 2009 (n 87), para 75; United Nations Juridical Yearbook 2009 at 219 (the summary of the debate) ('It was pointed out that, in addition to ensuring compliance with international obligations, the concept of the rule of law implied a law-creating process that would involve all States, thereby strengthening the fairness and legitimacy of international law').
} 
international rule of law highlights how international law and institutions pay deference to, and rely upon, political legitimacy attached to the national rule of law. 